\section{Grunnsolid om samfunnsmedisin}

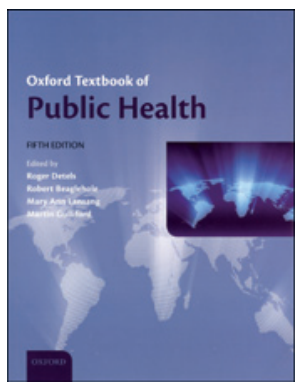

Roger Detels, Robert Beaglehole,

Mary Ann Lansang et al, red.

Oxford textbook of public health

5. utg. 1769 s, tab, ill. Oxford: Oxford

University Press, 2011. Pris GBP 145

ISBN 978-0-19-969347-4

Dette er 5. utgave av Oxford textbook of public health. Den er totalrevidert og har i tillegg fått en rekke nye kapitler. Det er nå fire redaktører som kommer fra hvert sitt kontinent. Antallet bidragsytere har økt til 223, alle internasjonalt ledende innen sine fagområder. Blant disse er også direktøren for WHO, Margareth Chan.

Det er tre hoveddeler. I den første delen beskriver bidragsyterne de største og viktigste samfunnsmedisinske utfordringene $\mathrm{i}$ dag. Den neste delen omhandler de analytiske redskapene i samfunnsmedisin, og i siste del beskriver de hvordan dagens kunnskap kan omsettes i praksis.

Forfatterne tar opp et bredt spekter av problemstillinger. Noen få stikkord er de samfunnsmedisinske konsekvensene av den raske urbaniseringen av jordens befolkning, globaliseringens muligheter og problemer, klima og helse, væpnede konflikter og terror, sosial rettferdighet på tvers av landegrensene, ernæring og livsstilssykdommer, alkohol og narkotika, sosiale helsedeterminanter, arbeidsledighet, helsepolitikk, menneskerettigheter og etikk. I tillegg blir det gitt en oppdatert og grundig analyse av den globale hiv/aidssituasjonen, av malaria, tuberkulose og potensielle pandemiske infeksjonssykdommer. Forfatterne beskriver også årsaker til og følger av en rekke sykdommer i et samfunnsmedisinsk perspektiv. Hele 250 sider er viet epidemiologiske og biostatistiske metoder som brukes i samfunnsmedisin.

Denne boken erstatter ikke de nasjonale lærebøkene i samfunnsmedisin. Spesifikke norske forhold må fortsatt beskrives i egne lærebøker. Men samfunnsmedisin er i dag et fagområde som i økende grad går ut over nasjonale grenser. For å forstå vår tids store samfunnsmedisinske utfordringer trenger vi derfor en akademisk, grunnsolid lærebok som denne. Boken er helt nødvendig som et oppslagsverk for alle medisinske og helsefaglige utdanningsog forskningsinstitusjoner, for helseforetakene og for offentlige kontorer hvor man arbeider med samfunnsmedisinske problemstillinger lokalt, nasjonalt og globalt. Den er for stor til å kunne anbefales som en lærebok for medisinstudenter. Men den bør foreligge som et tilbud til spesielt interesserte studenter, og den bør anbefales for dem som ønsker å fordype seg i fagområdet samfunnsmedisin.

Paperbacken er i stort format på 1769 tettskrevne sider. Det kan innvendes at en så stor bok burde vært utgitt i to eller tre bind. Her er det selvsagt et spørsmål om pris. 145 GBP er den i hvert fall verdt.

Oxford textbook of public health er resultatet av et vellykket samarbeidsprosjekt, og den er utvilsomt den mest omfattende læreboken i samfunnsmedisin som foreligger i dag. Den representerer en imponerende samling oppdatert kunnskap og viser hvor viktig samfunnsmedisinsk kunnskap er i det 21. århundre. Jeg anbefaler den varmt for alle som vil se dagens samfunnsmedisinske utfordringer i et globalt perspektiv.

\section{Kjell Haug}

Institutt for samfunnsmedisinske fag

Universitetet i Bergen

\section{Oversiktleg og «djupt» om dykkemedisin}

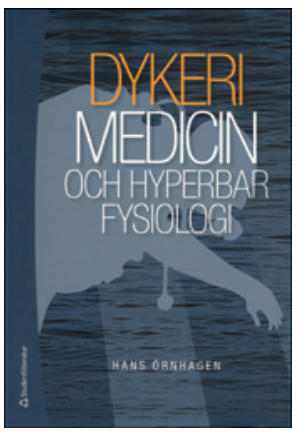

Hans Örnhagen

Dykerimedicin och hyperbar fysiologi

352 s, tab, ill. Lund: Studentlitteratur, 2011

Pris SEK 408

ISBN 978-91-44-05827-6

Forfattaren har vore sentral i europeisk dykkemedisin i over ein mannsalder og er nok den i Skandinavia som er best skikka til å skrive ei slik bok. Han er pensjonist, men framleis förbundsläkare i Svenska Sportsdykarförbundet. To av hans tidlegare publikasjonar er omtalte i Tidsskriftet $(1,2)$.

Boka er tilpassa krava for utdanning av legar i dykkemedisin gitt av European Diving Technology Committee (EDTC) og European Council for Hyperbaric Medicine (ECHM). Der er 17 kapittel som omfattar alt frå ulike former for dykking, relevant fysikk, verknadar av opphald i vatn, verknadar av aktuelle gassar under trykk, inertgasstransport i organismen, dekompresjonssykje («dykkarsykje»), kvinner og dykking, dykking ved sjukdom og medisinering, helseundersøking av dykkeaspirantar, skadar og dødsfall, og ubåtmedisin. Til slutt er det ei liste over annan relevant faglitteratur og ei liste over faguttrykk, samt eit sakregister.

Boka kan brukast som lærebok og oppslagsbok. Der er rikeleg med forklarande tabellar, figurar og strekteikningar. Språket er lettfatteleg svensk, og stilen er uformell og lettlesen, nærast munnleg. Men eg skjønar ikkje kvifor forfattaren har forsøpla det vakre språket med ein flora av uturvande anglisismar.

Dr. Örnhagen har god kunnskap om norske tilhøve, omtalar norsk regelverk og siterer norske statistikkar. Det gjer boka svært aktuell også her i landet. Som supplement til, eller erstatning for engelskspråkleg litteratur, er ho framifrå. Det finst inga like omfattande norsk bok av dette slaget, sjølv om Norske Dykke- og behandlingstabeller (3) og Froskemannen (4) frå Sjøforsvaret er svært gode og nærast uunnverlege til sitt bruk.

Papiret er godt, dei halvstive permane er av plastmateriale, og innbindinga er sterk og sydd. Trykkfeil er nærast fråverande. Dei fleste fagområde har sitt «stammespråk» med tilhøyrande forkortingar, så også her. I neste utgåve (eg reknar med at dette vert ein klassikar) bør forkortingane forklarast i lista over faguttrykk.

Forfattaren siterer flittig frå annan litteratur, med namn og årstal, men utan å gi sitata ein referanse. Det bør også rettast på i neste utgåve.

Dette er ei bok alle som syslar med dette fagområdet vil ha nytte og glede av, som innføring for nybyrjarar, som repetisjon eller oppslagsbok.

\section{Otto Inge Molvær}

Førde i Hordaland

\section{Litteratur}

1. Molvær Ol. Skandinavisk dykkemedisin. Tidsskr Nor Lægeforen 1991; 111: 1150.

2. Molvær Ol. Kort og godt om hyperbar oksygenbehandling. Tidsskr Nor Lægeforen 1994: 114: 1503-5

3. Arntzen A-J, Eidsvik S, Risberg J. Norske dykke- og behandlingstabeller. 3. utg. Loddefjord: Barotech, 2004

4. Gundersen G. Froskemannen: lærebok i dykking. Bergen: KNM Tordenskjold/ Dykker- og Froskemannskolen, 2009. 